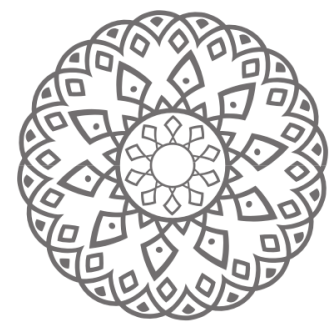

\title{
Outgroup Contact in the Process of Leaving Terrorism: Qualitative Study on DERADICALIZATION AND DISENGAGEMENT AMONG Former Jamaah Islamiyah MEMBERS IN INDONESIA
}

\author{
Gazi Saloom
}

\begin{abstract}
Leaving terrorism is a real thing that happened among Indonesian terrorists. Nevertheless, some experts and laypersons often do not believe that terrorists will leave their groups and their ideology. This study scrutinized leaving terrorism among Indonesia terrorists and push factors that lead to their transformation to be moderate and refuse violence in the pursuit of their goals. This study is based on interviews with five members Jamaah Islamiyah and twenty-five people that are related to them from friends and families. This study confirms that out-groups contact, including the targeted out-groups contact, becomes an important push factor for the subject to leave terrorism.
\end{abstract}

Keywords: Out-groups contact, terrorism, push factor. 
Abstrak: Meninggalkan jalan terror adalah peristwa nyata yang terjadi di kalangan teroris Indonesia. Banyak ahli dan kaum awam yang tidak percaya bahwa terrorist bisa meninggalkan ideologi dan kelompok teroris. Studi ini mengkaji tentang meninggalkan jalan terror di kalangan mantan pelaku teror dari Jamaah Islamiyah termasuk menjelaskan faktor apa yang mendorong perubahan mereka menjadi kaum moderat dan bahkan menolak teror dan kekerasan dijadikan sebagai cara untuk meraih tujuan politik dan keagamaan. Studi ini menggunakan metode kualitatif dengan wawancara mendalam dan telaah literature sebagai instrument utama pengumpul data dan informasi. Lima mantan anggota Jamaah Islamiyah dan dua puluh lima orang yang dianggap memiliki kaitan yang relevan dengan kelima orang tersebut dijadikan narasumber dalam penelitian ini. Studi ini mengkonfirmasi bahwa kontak dengan individu di luar jaringan merupakan faktor pendorong krusial yang mendorong individu keluar dari jaringan dan ideologi teror.

Kata Kunci: Outgroup, kontak, terorisme, faktor pendorong 


\section{Introduction}

NA, the former leader of Jamaah Islamiyah for South Asian, including Indonesia, came from Malaysia and currently lives in Indonesia. He has become one of those who decided to leave terrorism and the radical group, Jamaah Islamiyah. NA left Jamaah Islamiyah and terrorism because of several factors, including his long interaction in the former Christian members of Coker gang from Maluku (Nasir: 2005). However, it is important to note the interaction with individuals from disliked groups is not the only factor that contribute to someone's decision to leave terrorism.

When NA was a member of Jamaah Islamiyah, he was strongly indoctrinated that the most dangerous enemy of Muslims (ummah) is Christians who dislike Muslims and dominate the political stage all over the world, including Indonesia and other countries in South East Asia (Nasir: 2005). This indoctrination, to some extent, makes some radical group members target churches in their actions. This is because, in their perception, churches have been used by the Christians as a place to plan their actions in destroying and fighting Muslims (Imron: 2010). The doctrine that Christians and Jews always dislike Muslims made NA to have negative thoughts and feeling toward Christians.

AI, who has been jailed in the special prison for drug abuse in Jakarta Police Headquarter, has felt the same as NA. Eventually AI evaluated his thoughts and ideology about violent jihad and the establishment of Islamic States. In the end, he decided to leave terror and violent ways in pursuing his ideal. His new perception and understanding emerged after his interaction with Muslim and Christian police officers (Imron: 2010). It was mentioned that NA has entered de-radicalization step. In other word, NA has totally left radical Islamic ideology. AI, on the other hand, has impenetrated de-radicalization or he has left terror and violent ways in pursuing his ideological goals, but never leave his effort to apply sharia. His passion to implement Islamic law would never be weaken (Horgan: 2011, 56).

Two cases above are related to concept of de-radicalization and disengagement from or leaving terrorism. This usually becomes the topic in the field of psychology of radicalism and terrorism. De-radicalization and disengagement from terrorism is critical in eradicating Islamic 
radicalism and terrorism (Bjorgo \& Horgan, 2009:17-29). Even though there are many critics addressed to this concept and its effectiveness in preventing violent radicalism and terrorism, but. According to some studies and experts, this concept is still needed in fighting terrorism. Besides, militaristic methods have deemed to be insufficient to resolve the issues, including in Indonesia (Darvis: 2002). Instead of combating radicalism, the militaristic way precipitates a revenge reaction from the terrorists, their families and collegues. As the consequence, radicalism and terrorism is recycled and tranformed into other acts by new organizations or new younger members.

Therefore, it is expected that the de-radicalization and systematic and structural disengagement from terrorism can be one of effective strategies in eradicating violent radicalism and terrorism. In this context, there is a need to scientifically and empirically investigate push factors among the terrorists in leaving their violent ideology. With this knowledge, appropriate and effective programs to prevent and eradicate radicalism and terrorism can be better designed.

There have been several studies conducted to scrutinize the push and pull factors in leaving terrorism. A study by Horgan (2009), for example, found that there at least two factors that influence someone to leave terrorism. These factors are psychological and physical factors. The study by Horgan and his colleagues found that the decision to leave terrorism was due to the dissatisfaction towards the group's actions and its means to achieve ideological goals. Other findings suggested that avoiding the group physically can affect the decision to leave terrorism. This finding is understandable because social influence often occurs in an intensive interaction among radical or terrorist group members (Horgan: 2009, 17-29). Therefore, social-physical distances can minimize the opportunity for social influence to take place.

Another study on leaving terrorism was conducted by Reinares et al. (2011) in Europe. This study found that the radicalization and disengagement is related several factors such as 1) the change of personal perceptions about how the members of terrorist group make relationship with each other; 2) the change of perceptions among the leaders and members about strategies used by the group in achieving ideological goals; 3) and the shift in perception about socio-political situation and the context of conflicts (Reinares: 2011). 
In the context of de-radicalization and disengagement, it can be said that only few studies have been done in scrutinizing the role of outgroup contacts, particularly with prejudiced targets. In this case, I assume that the contact with outgroup members has a vital role in motivating people to evaluate and change their perception about radicalism and terrorism. Therefore, research that focuses on the role of outgroup contact is needed in order to be an academic basis in constructing psychological intervention and its application in eradicating and preventing terrorism. The Contact with out-group members, as a critical element in behavioural change, is one of the central issues in social psychology, particularly related to intergroup relations (Baumeister: 2010, 5-24).

The notion that outgroup contact can be an alternative solution in eradicating and preventing terrorism is based on the assumption that any political violence is highly related to intergroup prejudice and hostility. Almost all experts of social sciences, including those of social psychologists, assert that no terrorism behaviour except is done in a group or team. It can be said that prejudice and hostility among the groups happen because every group or every member of the group has no adequate information about other groups or its members. This makes prejudice and spontaneous appraisal become a reference to evaluate each other.

In that case, an act of terror or terrorism is an act related to group behavior and intergroup behavior. In general, the motivation that pushes the act of terror of any group is highly related to intergroup bias, such as prejudice and hostility toward some people. Prejudice and hostility are pivot causes of collective esteem fall. In that situation, strong identification toward the group becomes more salience, solidarity among members of the group becomes stronger, and their desire to defend the group is hard to avoid.

Kruglanski et al. underlined the quest for significance as a push factor of the radicalisation process, including among Islamist terrorists. Kruglanski et al, further, pointed out that three factors in radicalization process related to the quest for significance, mainly: 1) the desire to be meaningful or to be significant; 2) self-identification as a terrorist and making of violence as a tool to gain significance; 3) the change of commitment toward the goal of significance and avoiding other 
motivation than terrorism or violence as the main motivation in several activities (Kruglanski, et al.: 2014, 69-93)

The need for significance is hardly avoided in life. Amount of energies are used to pursuit tranquillity, to survive and to be healthy (Kruglanski, et al.: 2011). Kruglanski et al. (2014) suggested that the quest for significance can be activated through three ways: first, through the loose of personal significance or feeling humilited, which is related to the concept of deprivation in psychology and sociology. Second is through fear or feeling threatened of loosing the significance, which in psychology, is explained by the concept of avoiding. Third is through an opportunity to get significance, which is related to the concept of incentive or reward in the psychological perspective (Kruglanski, et al.: 2014, 69-93).

In that case, a desire to be significant for the group is the most important motivation to explain individuals' decision to join a terror group or to do an act of terror (Kruglanski, et al: 2009, 331-357). As behavior not only consists of group behaviour elements but also intergroup behaviour, the latter can also explain why people leave terrorism, its groups, and ideology (Fathali: 2007, 69-80).

Based on the above explanation, this study explains why the artificial significance and desire to defend through terror changes when an individual interact with other individuals or groups that used to be the target of prejudice and hostility. Therefore, this study aims at addressing several questions: First, is outgroup contacts effective to push the process of leaving terrorism in Indonesia? Second, how can psychological process and its mechanism explain the role of outgroup contact to push leaving terrorism in Indonesia? Third, in what context and situation the outgroup contact are effective to push the process of leaving terrorism?

\section{Deradicalization and Disengagement}

Deradicalization and disengagement are used to explain leaving terrorismsm (Gazi: 2006). Deradicalization is to leave s radical ideology that is full of violence. In other word, the term is used to explain that an individual does not embrace a radical ideology anymore, which influenced his/her life and behaviour for years (Horgan: 2011, 56). 
Disengagement, on the other hand, is used to explain someone's inclination for leaving terrorism and violence in achieving the group's goals, although such ideology still remains in his/her cognition.

Based on the experience of some countries including Indonesia, the deradicalization program is usually focused more on dialogue and debate about particular ideology between the participants and clerics or 'ulama who have moderate Islamic thoughts (Barret \& Bokhari: 2008; Abuza: 2009; Boucek: 2009; Ashour: 2009). It is mentioned that the focus of deradicalization on ideology can lead to high costs and consequences, especially when the ideology is based on the holy book that is deemed as a sacred source for its believers (Ashour: 2009; Horgan: 2011; Amirsyah: 2012).

Apart from that, the deradicalization program organized by the government is often seen as the process of de-Islamization by some people. According to this people, the program must be refused due to the denial againts the concept of jihad, which in their opinion, has strong basic argument in the Quran (Amirsyah: 2012).

With regards to the psychological theory about the relationship between attitude and behavior, there has been a debate on whether the attitude influences behavior or the other way around. This questions have been posed by experts and researchers in the field of behavioral sciences (Baumeister: 2010, 5-24). The similar question can also be asked in investigating the relationship between deradicalization and disengagement. Can deradicalization predict disengagement, or, on the contrary, can the disengegement predict deradicalization?

Theorectically, it can be said that deradicalization can predict disengagement or leaving ideology can explain leaving terrorism, althought some researchers in the field of terrorism, such as Horgam (2009), suggest that the relationship between leaving ideology and choosing terror ways is not always linear. Bjorgo and Horgan explained that in many types of research that they did, it was found that deradicalization is not always related to leaving terrorism (Bjorgo \& Horgan: 2009). They found that some people claimed to have left terrorist group and terror ways, but they have never left their imagination about establishing an Islamic state.

Instead of contrasting between deradicalization and disengegement 
concepts, this paper prefers to combine both of the concepts to explain the definition of leaving terrorism. The two concepts will be regarded as two dimensions of leaving terrorism. The first dimension is that explain leaving terrorism in the domain of ideology. Whereas the second dimension is to explain the methods and strategies in leaving violence and terror ways in achieving the ideological goals among the terrorist groups (Gazi: 2009; Bjorgo \& Horgan: 2009).

Another questionable issue among scholars is about whether deradicalization process is the opposite of radicalization process? This question becomes crucial considering that there has been a polarization between the two issues. The first point of view says that deradicalization is not the opposite of radicalization. The second opinion, on the other hand, insists that the deradicalization process is certainly the opposite of the radicalization process (Kruglanski, et al.: 2014, 69-93).

Kruglanski suggests a solution by saying that the accepted indicators of personal transformation among terrorists, from violence to peace, is by seeing to what extent someone think moderately about socio-political issues and their relationship to religion, which in this case is Islam (Kruglanski, et al:: 2014, 69-93). In the context of Islamic thoughts and ideologies, moderate thoughts and ideologies are recommended alternatives since they are in line with message of the Quran (Yew-Foong: 2013). The Quranic term in describing moderation is wasatiyah as explained by Azyumardi Azra, a Muslim intellectual from Syarif Hidayatullah State Islamic University, Jakarta. Further, it is mentioned that moderate Islam is a unique characteristic of Islam in Nusantara, located between Indonesia, Malaysia and Singapore. Thus, an Islamist terrorist or Islamist radicalist can be deemed to abandon the radical Islamic ideology since he/she transformation into a moderate Islam (Kruglanski, et al.: 2014:69-93).

However, the remained question is when is someone considered a radical Muslim or a moderate Muslim? It is mentioned that there are three criteria for Islamic radicalism, which are the desire to establish Islamic state or Caliphate; the use of violent ways to achieve the goals of Islamic state; and intolerance towards diversity (Mirahmadi \& Farooq: 2010). Other scientists suggest that there are three models of Islamic radicalism in Indonesia: 1) radical in terms of ideology and methods in achieving goals; 2) radical in terms of ideology but not radical in 
term of methods; and 3) not radical in term of ideology but tends to be intolerant toward diversity and any violation againts Islamic law (Horgan: 2011, 56; Bjorgo \& Horgan: 2009, 17-29 ; Zachary: 2009, 193-211).

\section{Outgroup Contact and Increased Attitude}

Social psychologists have often used intergroup contact as a special term to explain out-group contact. It is mentioned that intergroup contact or out-group contact is face-to-face interaction that happens between two members or more of different groups (Pettigrew \& Tropp: 2006). The contact with another individual from another group is like two faces of a coin. In one hand, the contact consists of positive influence, and on another hand, it consists of negative influence. In another word, the contact with another individual from another group can enhance the perception toward the differences between two individuals, and between two groups. The positive influence of the contact is the enhancing of the feeling of similarity and proximity between two individuals and two groups (Guimond: 2006).

Experts and researchers of social behavior introduced the concept of intergroup contact after World War II as a tool to reduce intergroup conflict, in particular when they studied the relation between European American and African American in the United States. Nevertheless, it was found that positive intergroup contact only could not eliminate or reduce intergroup relation bias (Hogg \& Abrams, 1998). In that case, there are some intermediary variables that exist to reduce difference and bias in term of intergroup relation (Pettigrew \& Tropp: 2006).

Many experts in social behavior found that contact happened among members of different groups frequently creates competition and hostility. Nevertheless, other studies also found that intergroup contact could alleviate prejudice and hostility attitudes. For instance, the study by Turner and Crisp (2010) concluded that merely imagination of intergroup contact is adequate to alleviate prejudice toward other groups.

Another study using meta-analysis approach among 713 samples of 515 studies done by Pettigrew and Tropp (2006) found that intergroup contact could alleviate prejudice. Pettigrew and Tropp measure 
prejudice by using Implicit Association Test (IAT), a special computerbased measurement. The study found that non-Muslims who imagine talking with foreign Muslims showed more positive attitude toward Muslims in general (Pettigrew \& Tropp: 2006).

Positive impacts of intergroup contact on the quality of relationship have been explored by the founder of intergroup contact theory, Allport (1954). Allport underlined that intergroups contact should affect positively if it meet some conditions and stipulations. First, the contact happens in an equal situation between two groups. Second, the contact happens in a cooperation situation. Third, the contact is motivated by the same goal. Fourth, the contact is supported by social or state authorities (Dovidio \& Gaertner: 2003, 715-783).

It is confirmed that an intergroup contact could alleviate intergroup prejudice (Wagner \& Hewstone, 2012). This is based on the argument that the majority of intergroup conflicts have relied on negative interdependence, as mentioned by Deutsch (1949), or perception of a group about the possible failure of its goal or other groups' reaction to that goal, as in van Knippenberg's study (2003).

A study of intergroup contact was conducted by Deutsch and Collins in 1951 on the white and black Americans. This study found that the segregation of the two groups in one apartment strongly affected the acceptance toward others, more than those who live in a separated apartment (Wagner \& Hewstone: 2012).

The same notion has been suggested by Saloom in his study on the dynamic relation among Muslims and Hindus in Lombok island. Saloom (2009) affirmed that the settlement segregation for Muslims and Hindus is a significant factor that influence the conflict intensity and misunderstanding between Muslim-Sasak and Hindu-Bali ethnics. With reverse logic, the desegregation of two ethnics with two religions tends to alleviate intergroup prejudice and hostility (Wagner \& Hewstone: 2012).

It is mentioned that contacts with others from different groups could push individuals to find alternative views in assessing other individuals and other groups (Guimond, 2006). Besides, an intergroup interaction could complete and complement information and knowledge about other individuals and groups so that someone hardly to be caught in the snare of prejudice and negative appraisal (Baumeister: 2010). 


\section{Contact Dynamic and Leaving Terrorism}

Terrorism is not merely consisting of a group behavior dimension but also consisting of intergroup behavior. Therefore, it must be related to an intergroup relation (Moghaddam: 2007). This is because the act of terror committed by a group that is motivated by the solidarity toward people who have the same identity or by the desire to revenge for the death of significant others.

Diley et al.'s study (2012) found that the enhancement of social contact with other individuals out of the gang has been proven to be a significant factor among gang members to leave criminal world. The same thing has been found among the members of al-Qaida who left terrorism due to contacts with other individuals out of the group.

In the case of terrorism, Jacobson (2010) found that the contact with other individuals out of terrorist networks could be a push factor for deradicalization and disengagement. Jacobson exemplifies the case of Al-Rashid, Mushabib al-Hamlan, and Sajid Badat who cancelled their decision to the bombers of 9/11 attack planned by Al-Qaida. This was because they had an opportunity to have a telephone contact with their families. Apart from that, Sajid Badat had an opportunity to go home and meet his family. It was believed that such contact made him change his decision to be a bomber (Jacobson: 2010).

Other study on the influence of contact with other world was conducted by Hwang, Pangabean, and Fauzi (2013) in Poso, Indonesia. Their study, which focused on terrorists and radical Muslims in Poso, reveals that the interaction or communication with other individuals out of the group such as family and friends can be a push factor in leaving terrorism networks (Hwang et al.: 2014).

The question is why does a contact with other individuals out of the group can be a push factor for individuals in? The simple answer for this question is because the contact with other individuals out of the group can make the terrorists open-minded. An open-minded attitude can transform individuals' perceptions to be wiser in veiweing complicated social and political problems.

A study on radicalization process conducted by Moghaddam (2009) found that the more someone is isolated in staircases of terrorism, the harder he finds to leave the terrorism trap. Moghaddam 
also explained that there was efforts made by the seniors and mentors in the terrorist group to isolate the recruits in order to prevent them to have contacts with other individuals out of the group. This was because they want prevent the recruits from leaving the group (Jacobson: 2010) (Moghaddam: 2007).

\section{Method of the Study}

This study uses qualitative method with thematic research design. The participants of this study are five former of terrorists who were well-known by the Indonesian public. Apart from them, interviews were also conducted to 40 individuals who have friendship and kinship relations with those five people.

The five subjects of study are former members of Jemaah Islamiyah led by Abdullah Sungkar and Abu Bakar Baasyir who had involved in military training and/ or act of bombing in several places in Indonesia. These subjects are NA, AA, AI, Id and UP.

Table 1. Description of Study Subjects

\begin{tabular}{|c|c|c|c|}
\hline No. & Initial & Descriptions & Today activities \\
\hline 1 & NA & $\begin{array}{l}\text { NA is one of the former of } \\
\text { Jamaah Islamiyah leaders who } \\
\text { had presided Mantiqi Three that } \\
\text { included Sulawesi and Philipina. } \\
\text { NA came from Malaysia and } \\
\text { had taken military training } \\
\text { and education in an Afganistan } \\
\text { military camp. He was the } \\
\text { instructor of military training } \\
\text { in his almamater and Mindanao } \\
\text { island of Philipine. }\end{array}$ & $\begin{array}{l}\text { NA is now working as a partner } \\
\text { of the Indonesian Police and } \\
\text { the National Board for Anti } \\
\text { Terrorism; in particular, } \\
\text { he has helped the board in } \\
\text { deradicalization program. }\end{array}$ \\
\hline 2 & $\mathrm{AA}$ & $\begin{array}{l}\text { AA is a former advisor of Mantiqi } \\
\text { ukhra (Zone of Australia). He had } \\
\text { presided by his younger brother } \\
\text { with same initial name. Besides, } \\
\text { his educational background was } \\
\text { in Islamic Law and Arabic from } \\
\text { LIPIA, an A Saudi-sponsored } \\
\text { Islamic University in Jakarta. He } \\
\text { was well-known as a cleric who } \\
\text { embraces Salafi school. }\end{array}$ & $\begin{array}{l}\text { AA is now working as an } \\
\text { Islamic preacher; a teacher in } \\
\text { many Islamic teaching circles; } \\
\text { and also a member of expert } \\
\text { team in National Board of Anti } \\
\text { Terrorism. } \\
\text { AA lives in South Tangerang } \\
\text { Banten and has established an } \\
\text { Islamic foundation working in } \\
\text { the field of education, preaching } \\
\text { and disseminating Salafi schools. }\end{array}$ \\
\hline
\end{tabular}




\begin{tabular}{|c|c|c|c|}
\hline 3 & AI & $\begin{array}{l}\text { AI is the younger brother of } \\
\text { Amrozi and Ghufron, the two } \\
\text { of three convicted terrorists that } \\
\text { were punished with death penalty } \\
\text { together with Imam Samudra in } \\
\text { Nusakambangan Island. }\end{array}$ & $\begin{array}{l}\text { AI is now still jailed in Jakarta. } \\
\text { Occasionally, AA has been } \\
\text { asked to help the Police } \\
\text { Department and National Board } \\
\text { of Anti Terrorism conducting } \\
\text { rehabilitation activities through } \\
\text { direct discussions and debates } \\
\text { with new suspected terrorists. }\end{array}$ \\
\hline 4 & ID & $\begin{array}{l}\text { ID was the graduate of Pondok } \\
\text { Pesantren Al-Islam Ngruki Solo } \\
\text { and member of Jamaah Islamiyah. } \\
\text { He was involved in several acts of } \\
\text { bombing such as the Christmas } \\
\text { eve bombing in } 2000 \text { and Bali } \\
\text { bombing } 2 \text { in } 2002 \text {. }\end{array}$ & $\begin{array}{l}\text { ID is now working as a taxi driver } \\
\text { in Pekanbaru to meet his and his } \\
\text { family needs. }\end{array}$ \\
\hline 5 & UP & $\begin{array}{l}\text { UP was a member of Jemaah } \\
\text { Islamiyah and the convict of Bali } \\
\text { bombing } 2 \text {. This Arab descendent } \\
\text { was deemed as the most dangerous } \\
\text { people by America and Australia. } \\
\text { He got his military education } \\
\text { in Afganistan Mujahidin Camp } \\
\text { and also became an instructor for } \\
\text { military training in Mindanao } \\
\text { Philipine. }\end{array}$ & $\begin{array}{l}\text { Today, UP is still jailed in Sidoarjo } \\
\text { Surabaya. He was shocked the } \\
\text { Indonesian public due to his role } \\
\text { as the carrier of an Indonesian } \\
\text { flag in the ceremony to celebrate } \\
\text { Indonesian Independence Day } \\
\text { two years ago. }\end{array}$ \\
\hline
\end{tabular}

Data and information were collected through interviews, observations and documents review, including those of relevant social media. Data and information were analyzed with an qualitative technique analysis, mainly thematic analysis.

\section{Study Findings}

To confirm the assumption that all subjects have truly left terror ways, this study makes validation by mentioning it in the interviews with those subjects. Triangulation mechanism was done by asking the assumption to the participants and key informants; and by reconfirming their statements in social media and printed media. This mechanism can truly assert the participants' decision to leave terror ways.

In many kinds of literature, it is mentioned that a contact with other persons from different groups has an influence on the ideology and perceptions about other groups or the enemy. NA's experience, when he 
was jailed in one chamber with Coker Gang from Maluku, has changed his perception about Christian people in general. In his perception, the two members of Coker gang were very kind and respectful toward him. The two Christians often helped him in fulfilling his daily needs while he was in jail. NA clearly told the story about his experience in the interaction with Christians from Maluku.

"I was impressed with two Christians, the leader and the member of the Coker gang who was detained with me in one chamber. They were very kind and polite people. They were very respectful to me. I was very flattered. I think, since that time, I change my perception toward non-Muslims, particularly, toward Christians whom I was informed that they strongly hate Muslims and Islam. This was wrong. It was my experience that has changed my thought about Christians."

NA's experience in a long term and intensive interaction with other people or Non-Muslims has opened his eyes and his mind that his misunderstanding about the other groups has been due to his lack of information and close-minded personality. The existing literature on intergroup contact, such as Davies et al. (2013), asserts that friendship can make the quality of intergroup contact better than before. This notion is supported by Shelly Zhou et al. who found that direct friendship in intergroup contacts improve the attitude toward outgroup (Zhou, et al.: 2018).

AI, the younger brother of Amrozi and Mukhlas or Gufron, has had the same experience with NA in the process of leaving terrorism and the radical group. In the past, AI believed that the Indonesian government, including the Indonesian police, was his and his colleagues' enemy. In his eyes, police officers were people who must be responsible for the death of his friends and for destroying his group or community. The hatred for Indonesia filled his mind and feeling, body and soul. In his point of view, the Indonesian police dislikes Islam and Muslims because of they are unbelievers or kafir.

AI has changed his view about the suspected enemy of Islam and Muslims after intensive interactions and contacts with high and low police officers, who are Christians, in the headquarter of the Indonesian police department. AI explained his attitude toward Christians, including Christian police officers: 
“.... but to me... it is unclear whether all Christians agreed with what had been done by some Christians in Ambon and Poso. When I was detained, I met many Christian police and non-police officers who do not agree with such actions. In my conclusion, there are many good Christians who are kind to Muslims." (AI)

From AI's statement, it can be concluded that he is able to distinguish between good people and bad people among the members of other groups after long interactions with them. He has no longer generalized people on the basis of their group, rather he can differentiate variety of people among the members of a certain group.

ID also talked about his experience in the jail and when he was a taxi driver in Pekanbaru. In the jail, he felt that Christian police officers treated him good. When he has a taxi driver, he has often taken tourists from Australia to some places in Pekanbaru. He concluded that he was wrong about foreigners, because he has found that they have been very kind. According to ID, all of those experiences have changed his perception and attitude toward non-Muslims including Christian foreigners.

"My contact experiences with different people from different religious background and ethnicity and when I was a taxi driver has forced me to conclude that they are good people. They were not bad as what I imagined for long time." (ID)

ID insisted that his hostility and dislike for foreign people came from the indoctrination done by the senior or leader of the group when he was an active member of Jamaah Islamiyah. Some seniors or leaders of the group told him that all westerners and foreign people were enemies of Islam and Muslims, in particular Christians and the Jews. These two groups of the infidel people are always hostile to Islam and have aimed to destroy Islam and Muslim all over the world. In ID's past opinion, the Christians and the Jews used all ways and powers in order to dominate and control Muslims and Islam. ID realized that not all people are bad after a deep contemplation and having some experiential interactions with different people from different groups and ethnicities.

Another former member of radical group, AA, who is now working as a teacher of Islamic studies in many mosques and forums, expressed his thoughts and feeling about intergroup contacts and its relation to behavioural changes. As the leader and adviser of Jamaah Islamiyah in 
Australia, and a preacher, AA talked about his contact experiences with local citizens, in particular those who were non-Muslims. In his view, he never found any problems and obstacles in daily life such as business transactions and others. He never imagined that those people were targeted by Hambali in his attack. He eventually did not understand what motivate Hambali to bomb Bali where many foreign people enjoy their leisure times.

"I lived long times ago in Australia as a preacher and advisor of Jamaah Islamiyah for other mantiqi. I certainly interacted and contacted with many foreign people in Australia. For me, it was ordinary thing. In daily life, I used to meet them such as in business. It was ordinary thing. We need each other. With regards to daily interactions, the Prophet Muhammad ordered us to interact with whomever we meet in our daily life. The most important thing was our belief in God (imān) was safe and kept well." (AA)

UP also described the same thing. In his opinion, meeting with many individuals from different groups, religions and ethnicities has made him aware that the diversity was a gift and blessing from Allah to be thanked. UP said that he actually did not hate Christians and the Westerners. He just hates Israel because they colonized and occupied Palestine illegally.

"In this Jail (Porong Surabaya East Java), I have met and interacted with many people including non-Muslims such as Christians. I can find people who are different here, and I have not found any problem and obstacle. I tell you truly that I just hate Israel in relation to Palestine, not Christians or western people." (UP)

UP stressed that the only motivation to join a terrorist group was the hatred and resentment toward the Jews all over the world. In his opinion, the root cause of many tragedies faced by Muslims since a long time ago until this time has been the arrogance of the Jews in Palestine. However, I certainly believe that this statement is a kind of self defence mechanism that the participant used in order to avoid guilty caused by the social-order deconstruction of the Indonesian people when he and his colleagues blasted a bomb in Bali.

It is important to note that out-group contacts with other non-Muslim inmates, especially the Christians, have significant contribution to an individual's decision and choice to leave terrorism. In this context, it can be stated that out-group contacts can open the 
mind of the participants and render new information and knowledge about others.

\section{Conclusion}

Based on the data that I have presented before, it can be concluded that the contact with other individuals from other groups, particularly those who are the target of prejudice and hostility such as Christians, has a strong impact on the changing perception about enemies and the attack targets. In the context of this study, outgroup contact is one important factor that push terrorists to leave terrorism and their group.

Certainly, an out-group contact is not the only factor affecting leaving terrorism. Any behavior, according to psychological perspective, is not pushed by one factor only, including leaving terrorism (Baumeister: 2010). Similar to the radicalization process, joining a terrorist group and deradicalization and disengagement process are affected by multi factors, including personal, group and social factors (Gazi: 2016; Kruglanski, et, al.: 2011; Moghaddam: 2007; Reinares: 2011).

The contact with other individuals out of the group, combined with its positive experience, can create an opportunity for individuals to evaluate their social relationship in the past. The evaluation, in general, makes individuals aware that their perception about others or enemy, as suggested by other people, is not the same with their experience in the real life (Gazi: 2016).

Besides, a positive and enjoyable contact can push the subjects to evaluate and correct their identities. For long times, they intensively interacted and contacted with each other or with their seniors and leaders in the group. This makes their group identities to be more salient than their personal identities. Consequently, all of their physical and non-physical energies, including finance, were used for the interests of the group. In this case, personal interests or family interests were ignored (Gazi: 2016).

Other than identity issue, contact with other individuals from different groups can push the subjects to correct some values they had embraced for long periods. Group values, which often became the basis in viewing every issue, no longer become their psychological needs. Eventually, personal values become more salient than group values 
(Gazi: 2016). Positional shifting of identity and value from group domain to personal domain affect the independence of the subjects in making decisions including those that are related to leaving the group and the ideology of the group (Gazi: 2016).

In conclusion, an outgroup contact is effective in the process of leaving terrorism in Indonesia. Effectivity of outgroup contact will have an impact if it happens in a postive situation; in the situation where the personal identity is more salient than the group identity; and when personal value is stronger than group value.

\section{Acknowledgments}

My deepest gratitude to those who have given me motivations to finish this article. Among them are Prof. Hamdi Muluk, Dr. Mirra Noor Milla and other names I could not mention one by one, but not lessening my appreciations for them. I also thank the Ministry of Religious Affairs of Republic of Indonesia, especially the Directorate of Islamic Higher Education, for a four-year doctoral scholarship that was given to me (2010-2015) in the faculty of Psychology, Universitas Indonesia. Last but not least, I must thank The Rector of Syarif Hidayatullah State Islamic University for the grant to accomplish my dissertation writing.

\section{References}

Abbas, N. (2005). Membongkar Jamaah Islamiyah: Pengakuan Mantan Anggota. Jakarta: Grafindo Khazanah Ilmu.

Abuza, Z. (2009). The rehabilitation of Jamaah Islamiyah detainees in South East Asia: a preliminary assessment. Dalam T. Bjorgo, \& J. Horgan, Leaving Terrorism Behind: Individual and Collective Disengagement (hal. 193-211). Oxon: Routledge.

Amirsyah. (2012). Meluruskan salah faham terhadap deradikalisasi: pemikiran, konsep dan strategi pelaksanaan. Jakarta: Penerbit Grafindo Khazanah Ilmu.

Ashour, O. (2009). The De-Radicalization of Jihadists Transforming armed Islamist movements. New York: Routledge.

Barret, R., \& Bokhari, L. (2008). Deradicalization and rehabilitation programmes targeting religious terrorist and extrimist in the Muslim world. Dalam J. Horgan, \& T. Bjorgo, Leaving Terrorism Behind: Individual and Collective Disengagement (hal. 170-180). London: Routledge.

Baumeister, R. F. (2010). Social psychologists and thinking about people . Dalam 
R. F. Baumeister, \& E. J. Finkel, Advanced social psychology : the state of the science (hal. 5-24). New York: Oxford University Press, Inc.

Birru, L. (2010). Ketika nurani bicara. Jakarta: Yayasan Lazuardi Birru.

Birru, L. (2011). Kutemukan Makna Jihad. Jakarta: Lazuardi Birru.

Bjorgo, T., \& Horgan, J. (2009). Leaving terrorism behind: individual and collective disengagement. New York: Routledge.

Boucek, C. (2009). Extrimist reeducation and rehabilitation in Saudi Arabia. Dalam T. Bjorgo, \& J. Horgan, Leaving Terrorism Behind: Individual and Collective Disengagement (hal. 212-223). Oxon: Routledge.

Davis, J. M. (2002). Countering international terrorism: perspectives from international psychology. Dalam C. E. Stout, The Psyhcology of Terrorism: Program and Practices in Response and Prevention. volume Four. (hal. 33-56). Westport CA: Praeger.

Dovidio, J. F., Gaertner, S. L., \& Kawakami, K. (2003). Intergroup contact: the past, present, and the future. Group Process \& Intergroup Relations, 5-20.

Gazi. (2016). Dinamika relasi sosial dalam proses meninggalkan jalan teror. Depok: Disertasi di Fakultas Psikologi Universitas Indonesia.

Guimond, S. (2006). Social Comparison and Social Psychology: Understanding Cognition, Intergroup Relations, and Culture. New York: Cambridge University Press.

Hogg, M. A., \& Abrams, D. (1998). Social Identifications: A Social Psychology of Intergroup Relations and Group Processes. London: Routledge.

Horgan, J. (2009). Individual disengagement: a psychological analysis. Dalam T. Bjorgo, \& J. Horgan, Leaving Terrorist Behind: Individual and Collective Disengagement (hal. 17-29). New York: Routledge.

Horgan, J. (2011). Disengagement from terrorism. Journal of Personality and Social Psychology, 56.

Hwang, J. C., Panggabean, R., \& Fauzi, I. A. (2013). The Disengagement of Jihadis in Poso, Indonesia. Asian Survey, Vol. 53, Number 4, 754-777.

Imron, A. (2010). Ali Imron Sang Pengebom. Jakarta: Penerbit Republika.

Jacobson, M. (2010). Terrorist dropouts: learning from those who have left. Washington: The Washington Institute for Near East Policy.

Kruglanski, A. W., \& Orehek, E. (2011). The role of the quest for personal significance in motivating terrorism. Dalam J. Forgas, A. W. Kruglanski, \& K. William, The Psychology of Social Conflict and Aggression (hal. 153-166). New York: Psychology Press.

Kruglanski, A. W., Chen, X., Dechesne, M., Fishman, S., \& Orehek, E. (2009). Fully committed: suicide bombers' motivation and the quest for personal significance. Political Psychology Vol. 3 No. 3, 331-357.

Kruglanski, A. W., Gelfand, M. J., Belanger, J. J., Shaveland, A., Hetiarachchi, M., \& Gunaratna, R. (2014). The psychology of radicalization and 
deradicalization: How significance quest impacts violent extrimism. Advance in Political Psychology Vol 35, Supp 1. doi: 10.1111/pops.12163, 69-93 .

Krunglanski, A. W., \& Fishman, S. (2009). The psychology of terrorism: syndrome versus tool perspectives. Dalam J. Victoroff, \& A. W. Kruglanski, The psychology of Terrorism: Classic and Contemporary Insight (hal. 35-54). New York: Psychology Press.

Mirahmadi, H., \& Farooq, M. (2010). A community based approach to countering radicalization: a partner for America. Washington DC: World Organization for Resource and Education Development.

Moghaddam, F. M. (2007). The Staircase to Terrorism: A Psychological Exploration. Dalam B. Bongar, L. M. Brown, L. E. Beutler, J. N. Breckenridge, \& P. G. Zimbardo, The Psychology of Terrorism (hal. 69-80). Oxford: Oxford University Press.

Pettigrew, T. F., \& Tropp, L. R. (2006). A meta-analytic test of intergroup contact theory. Journal of Personality and Social Psychology. Vol. 90, No. 5, 751-783 DOI: $10.1037 / 0022-3514.90 .5 .751$.

Reinares, F. (2011). Exit from terrorism: A Qualitative empirical study on disengagement and deradicalization among members of ETA. Terrorism and Political Violence 23, 780-803 DOI: 10.1080/09546553.2011.613307.

Saloom, G. (2009). Dinamika Hubungan Kaum Muslim dan Umat Hindu di Pulau Lombok. Harmoni Nomor 30, 71-79.

Solahudin. (2011). NII sampai JI: salafi jihadisme di Indonesia. Jakarta: Komunitas Bambu.

Tropp, L. R. (2012). The Oxford Handbook of Intergroup Conflict. New York: Oxford University Press.

Turner, R. N., \& Crisp, R. J. (2010). Imagining intergroup contact reduces implisit prejudice. British Journal of Social Psychology 49, 129-142.

Wagner, U., \& Hewstone, M. (2012). Integroup contact. Dalam L. R. Tropp, The Oxford Handbook of Intergroup Conflict (hal. 193-2009). New York: Oxford University Press.

Yew-Foong, H. (2013). Encountering Islam : the politics of religious identities in Southeast Asia. Singapore: Institute of Southeast Asian Studies.

Zhou, S., Page-Gould, E., Aron, A., Moyer, A., \& Hewstones, M. (April 2018). The extended contact hypothesis: A meta-analysis on 20 years research. Personality and Social Psychology Review, DOI: 10.1177/1088868318762647.

Gazi Saloom, Universitas Islam Negeri Syarif HIdrayatullah Jakarta Indonesia.

E-mail: gazi@uinjkt.ac.id 